\title{
Cikkismertetés: Szektorokon átívelő partnerség és népegészségügy: Kihívások és lehetőségek a magánszektor bevonására az elhízás és nem fertőző betegségek területén
}

\author{
Article review: Cross-sector partnerships and public health: challenges and \\ opportunities for addressing obesity and noncommunicable diseases \\ through engagement with the private sector
}

Ismertető: $\quad$ Varsányi Péter $\square$
$\quad$ Nemzeti Népegészségügyi Központ

Ismertetett cikk: Johnston LM, Finegood DT. Cross-sector partnerships and public health: challenges and opportunities for addressing obesity and noncommunicable diseases through engagement with the private sector. Annu Rev Public Health. 2015 Mar 18;36:255-71. doi: 10.1146/annurev-publhealth-031914-122802

Beküldve: $\quad$ 2019. 03. 01.

doi: $\quad$ 10.24365/ef.v60i3.430

Kulcsszavak: komplexitás; érdekellentét; kockázatkezelés; rendszerszemlélet; bizalom

Keywords: complexity; conflict of interest; risk management; systems thinking; trust

Az elmúlt évtizedekben a magánszektorral való együttműködés egyre elfogadottabbá vált a népegészségügy területén, főként az alacsonyés közepes jövedelmû országokban előforduló fertőzéses megbetegedések visszaszorításában, azonban az utóbbi években az elhízás és a krónikus megbetegedések megelőzésében is gyakran előtérbe kerül.

A fejlett országokban az elhízás és a krónikus betegségek előfordulása egyre nagyobb méreteket ölt, ezért kiemelt területnek számítanak a népegészségügyi beavatkozások szempontjából. Nyilvánvalónak tûnhet az ilyen kiemelt egészségkockázatok elleni fellépésben az ágazatokon átívelő együttműködés, azonban a dohányzás-visszaszorítás területén tapasztalt negatívumok némileg árnyalják ezt. A magánszektorral való együttműködés kritikusai főleg az összeférhetetlenséget, a közszféra szerepének és felelősségének gyengülését, valamint a népegészségügyi beavatkozások hatékonyságának gyengülését emelik ki, míg támogatói szerint a partnerség fontos eszköze lehet a kollektív fellépésnek, és potenciális életmentő beavatkozásokat biztosíthat. Az együttmúködéstől leginkább az üzleti életben fellelhető erőforrások hasznosítását, valamint a magánszektor egészséggel való kapcsolatának megváltozását várják a népegészségügy oldaláról.

A közleményben a lehetséges kockázatok kezeléseként azt javasolják, hogy a népegészségügyi szakemberek minden együttmúködés előtt vizsgálják meg, hogy a magánszektorral kialakított partnerség egyértelmúen segít-e elérni a kitǔzött célokat, és hogy a potenciális partnerek tevékenységei megegyeznek-e az egészségesebb társadalom tágabb értelemben vett elképzeléseivel. Fontos szem előtt tartani, hogy az együttmúködések a legritkább esetben szolgálják egyformán mindkét fél érdekeit, legtöbbször az erősebb partnerek érdekei érvényesülnek. A közleményben idézett szakértők három kérdést fogalmaznak meg, amelyet érdemes a szakpolitikai döntéshozóknak megfontolniuk, mielőtt együttmúködést kötnek a magánszektorral. Először is, gyorsabban és hatékonyabban fog-e megvalósulni a kitűzött cél az együttmúködés eredményeképpen; másodszor, 
a két fél érdekei fokozzák vagy fenyegetik-e a hosszabb távú népegészségügyi célkitűzések megvalósításának valószínűségét; és harmadszor, valódi partnerség vagy lazább kölcsönhatásforma tudná leghatékonyabban elérni a kitűzött célt. Ezen kérdések mérlegelése csökkentheti az együttműködés kockázatait. [1. táblázat]
A közleményben további példákon keresztül vizsgálják meg az együttmúködések kihívásait, előnyeit, kockázatait és megpróbálják szakirodalmi példák alapján megfogalmazni a sikeres együttmúködés jellemzőit a bizalom, az összeférhetetlenség és a monitorozás szempontjából.

\section{TANULSÁGOK A HAZAI SZAKEMBEREK SZÁMÁRA}

A népegészségügyi problémák megoldására létrejövő, magánszektorral való együttmúködések számos probléma forrásai lehetnek, azonban ezen problémák jelentős többsége előre látható és így kezelhető is. A közlemény számos példán keresztül mutatja be, mire kell kiemelt figyelmet fordítani, hogy egy ilyen együttmúködés a lehető legsikeresebb legyen mindkét fél számára.

\section{1. táblázat: A sikeres partneri együttmúködés kihivásai, kockázatai, előnyei és kritériumai}

\begin{tabular}{|c|c|}
\hline $\begin{array}{l}\text { Partnerség során } \\
\text { megfontolandó } \\
\text { szempontok }\end{array}$ & Partnerségben rejlő lehetséges problémák a szakirodalom szerint \\
\hline Kihívások & $\begin{array}{l}\text { - A nyelvi és szervezeti kultúrában lévő különbségek } \\
\text { - } \quad \text { Egymás szerepének nem megfelelő elismerése az együttműködés során } \\
\text { - } \quad \text { Nehézség a felelősségre vonhatóság mértékének megállapításában és a } \\
\text { teljesítmény mérésében }\end{array}$ \\
\hline Kockázatok & $\begin{array}{l}\text { - Az együttmúködő szervezet céljainak vagy vállalati kultúrájának hanyatlása, } \\
\text { önállóságának elvesztése } \\
\text { - } \quad \text { Az üzleti élethez mérten az állami bürokrácia lassú reakcióideje } \\
\text { - } \quad \text { Egyenlőtlen hatalmi kapcsolatok, amelyek negatív hatásúak lehetnek a } \\
\text { gyengébb fél számára } \\
\text { - Összeférhetetlenség } \\
\text { - } \quad \text { A felelősségre vonás nehézsége } \\
\text { - } \quad \text { Az együttmúködés miatt romló megítélés az állami és nonprofit szektorokban }\end{array}$ \\
\hline Előnyök & $\begin{array}{l}\text { - Hozzáférés az erőforrásokhoz, a szakértelemhez és a tudástranszferhez } \\
\text { - Jobb szolgáltatás, ellátás } \\
\text { - } \quad \text { Eltérő nézőpontok alkalmazása a szociális problémák megoldására } \\
\text { - } \quad \text { A célok és érdekek egyesítése a másik szektor kulturális normáinak } \\
\text { elfogadásával }\end{array}$ \\
\hline $\begin{array}{l}\text { Sikeres } \\
\text { együttmúködés } \\
\text { kritériuma }\end{array}$ & $\begin{array}{l}\text { - } \quad \text { A stratégia, a küldetés és az értékek összehangolása } \\
\text { - } \quad \text { A szektorok vezetői közötti személyes kapcsolat létrejötte } \\
\text { - } \quad \text { Bizalom és egymás kölcsönös tisztelete } \\
\text { - } \quad \text { Jó kormányzási gyakorlat (a képviselet, az átláthatóság és az } \\
\text { elszámoltathatóság tekintetében) } \\
\text { - } \quad \text { A partnerek eltérő érdekeinek elismerése és tiszteletben tartása } \\
\text { - } \quad \text { Források biztosítása a partneri együttműködéshez } \\
\text { - } \quad \text { Erős projektmenedzsment, egyértelmű elvárásokkal az előnyöket, } \\
\text { - } \quad \text { szerepeket és felelősséget illetően } \\
\text { - } \quad \text { Egyenrangús és nem alárendelt kapcsolatok egyenlő hatalommal, befolyással } \\
\text { - } \quad \text { Az értékelés és ellenőrzés beépítése a folyamatokba }\end{array}$ \\
\hline
\end{tabular}

Forrás: saját szerkesztés Johnston és Finegood (2018) alapján 